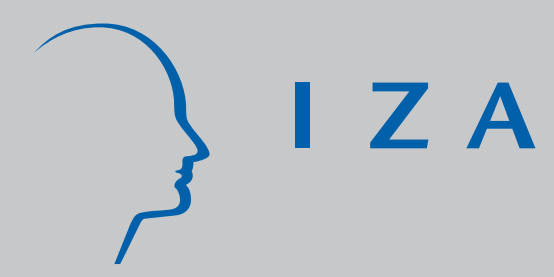

IZA DP No. 2678

Earnings, Schooling and Economic Reform:

Econometric Evidence from Hungary (1986-2004)

Nauro F. Campos

Dean J olliffe

March 2007 


\title{
Earnings, Schooling and Economic Reform: Econometric Evidence from Hungary (1986-2004)
}

\author{
Nauro F. Campos \\ Brunel University, \\ CEPR, WDI and IZA \\ Dean Jolliffe \\ Economic Research Service, USDA, \\ NPC, WDI and IZA \\ Discussion Paper No. 2678 \\ March 2007 \\ IZA \\ P.O. Box 7240 \\ 53072 Bonn \\ Germany \\ Phone: +49-228-3894-0 \\ Fax: +49-228-3894-180 \\ E-mail: iza@iza.org
}

\begin{abstract}
Any opinions expressed here are those of the author(s) and not those of the institute. Research disseminated by IZA may include views on policy, but the institute itself takes no institutional policy positions.

The Institute for the Study of Labor (IZA) in Bonn is a local and virtual international research center and a place of communication between science, politics and business. IZA is an independent nonprofit company supported by Deutsche Post World Net. The center is associated with the University of Bonn and offers a stimulating research environment through its research networks, research support, and visitors and doctoral programs. IZA engages in (i) original and internationally competitive research in all fields of labor economics, (ii) development of policy concepts, and (iii) dissemination of research results and concepts to the interested public.
\end{abstract}

IZA Discussion Papers often represent preliminary work and are circulated to encourage discussion. Citation of such a paper should account for its provisional character. A revised version may be available directly from the author. 


\section{ABSTRACT \\ Earnings, Schooling and Economic Reform: Econometric Evidence from Hungary (1986-2004) ${ }^{*}$}

How does the relationship between earnings and schooling change with the introduction of comprehensive economic reform? This paper sheds light on this question using a unique data set and procedure to reduce sample selection bias. Our evidence is from consistently coded, non-retrospective data for about 4 million Hungarian wage earners. We find that returns to skill increased by 75 percent from 1986 to 2004 (that is, during the period stretching from communism to full membership in the European Union). Moreover, our results identify winners and losers from reform. Winners were the college and university educated and those employed in the services sector (which excludes those in public services). Our results show that reform losers were those in construction and agriculture, those who attained only primary or vocational education (who actually experience a decrease in the returns to their education) as well as those younger workers which acquired most of their education after the collapse of communism (that is, after the main reforms were in place).

JEL Classification: $\quad$ I20, J20, J24, J31, O15, O52, P20

Keywords: $\quad$ human capital, transition economies, economic reform

Corresponding author:

Nauro F. Campos

Department of Economics and Finance

Brunel University

Uxbridge, Middlesex UB8 3PH

United Kingdom

E-mail: Nauro.Campos@brunel.ac.uk

\footnotetext{
* The authors are grateful to Tim Barmby, Elizabeth Brainerd, John DiNardo, Peter Dolton, Francisco Ferreira, Randall Filer, Stepán Jurajda, Harmut Lehmann, Jaime de Melo, Branko Milanovic, three anonymous referees and seminar participants at the Universities of Queen's Belfast, Bristol and Newcastle, BOFIT, World Bank Inequality and Pro-Poor Growth Conference and the Northeast University Development Consortium Conference for valuable comments on previous versions. We also thank János Köllo, Gábor Kezdi, Gábor Kõrösi and György Lázar for help with the data, and Dana Žlábková and Ján Plánovský for excellent research assistance. This work benefited from financial support from Phare ACE Grant 97-8085. The views and opinions expressed in this paper do not reflect the views of the Economic Research Service of the U.S. Department of Agriculture. The usual disclaimer applies.
} 
The rise and demise of communism are arguably the two most important economic events of the twentieth century. One of communism's indisputable achievements was an egalitarian distribution of income, which was accomplished in large part by wage compression. Returns to skill were determined centrally with wages set below equilibrium. The transition from centrally planned to market based economy was to have powerful effects. First, the liberalization of labor markets was expected to significantly raise returns to skill as these were artificially compressed under communism. Second, at least until the collapse of communism a large share of the labor force used vastly outdated technologies and one would not expect those specific skills to be valued in a market economy. Third, such skill deterioration would have been accompanied by a devaluation of the labor market experience acquired during communism. Fourth and finally, the transition from centrally planned to market economy involved sharp reductions in government education expenditures, which could have translated into education of lower quality. ${ }^{1}$ The aim of this paper is to put forward econometric evidence that throws light on these effects using unique data from Hungary from 1986 (that is, before the fall of communism) to 2004 (the year it became a member of the European Union).

In light of Hungary's obvious importance, the paucity of published studies about it is very surprising. Despite the fact that it was one of the most liberalized economies in the Soviet bloc, Hungary started the transition from communism opting for a gradualist approach to reform albeit with a distinctive (welcoming) attitude towards foreign investors. ${ }^{2}$ In addition to focusing

\footnotetext{
${ }^{1}$ These effects are seldom independent. Although socialism compressed earnings, it may have rewarded different skills in non-pecuniary terms. The anecdotal evidence points to vacations and access to consumer goods as such rewards.

${ }^{2}$ Further details about macroeconomic developments and labor market reform in Hungary are provided in Supplemental Appendix S.1 available at http://wber.oxfordjournals.org/
} 
on an economy that we believe has not received commensurate attention, ${ }^{3}$ ours is one of the few papers examining labor markets in transition economies to use sufficiently large and representative samples of wage earners before, during and after $^{4}$ the introduction of massive economic reform. ${ }^{5}$ The data we use cover almost 4 million wage earners from 1986 to 2004, and allow us to address the bias from selection on observables based on a technique proposed by DiNardo, Fortin and Lemieux (1996).

Our main findings are: (1) that returns to a year of schooling increased by 75 percent from 6.1 percent in 1986 to 10.7 percent in 2004; (2) that general secondary, college and university education show the largest changes in returns from 1986 to 2004, while vocational and primary education actually show a decline in returns; and (3) that the largest changes in returns to skill are for those employed in services, while the smaller changes are for those in construction and agriculture.

How do these findings relate to the effects of the introduction of massive economic reform mentioned above? Figure 1 shows that the liberalization of the Hungarian economy was

\footnotetext{
${ }^{3}$ Svejnar (1999), Boeri and Terrell (2002) and Fleisher et al. (2005) provide excellent reviews of the literature on returns to schooling in transition economies, while Card (1999) reviews this literature for non-transition countries. See Supplemental Appendix S.2 for a brief discussion of the literature.

${ }^{4}$ Despite its volume, this literature has few studies that present estimates for the period before and after reform as data availability is the binding constraint. Data collected before 1989 exist but most have to be extensively re-coded. Ours is unique in this respect: primary data were re-coded to current standard international classifications. Two of the main drawbacks of our data are that it does not contain information on self-employment or actual hours worked. Fleisher et al. note the lack of studies that deal with under-reported economic activity and/or the informal sector. They report that only about 14 percent of the estimates of returns to skills in transition economies are corrected for hours worked and that "when earnings data are adjusted for hours worked, estimated returns to schooling are not significantly larger" (2005, p. 363).

${ }^{5}$ From the economic reform literature, empirical evidence is scarce (for reviews of this literature see Rodrik, 1996, and Harrison and Hanson, 1999). Existing studies tend to compare effects at two points in time (before and after), focus on a single aspect of reform (for instance, trade liberalization) and assume that (a) the reform was effectively implemented and (b) sufficient time has transpired to measure its impact. We try to overcome these difficult issues by studying an unambiguously broad and effective reform at multiple points in time before and after its introduction.
} 
somewhat more intense than that of other transition economies and our results suggest that a link can be made between progressively rising returns to schooling and the progressive liberalization of the Hungarian economy. Returns to skill increased rapidly overall, but this increase was much smaller for those employed in construction and in agriculture and those with vocational (narrow) secondary education. These findings support the notion that the changes in returns to education during the transition process may be taken as indicator of the deepening of the reform process itself.

The rest of the paper is organized as follows. Section I describes our data and methodology. Section II presents our econometric results. Section III presents our main conclusions and distills their implications for policy.

\section{DATA AND THE EMPIRICAL SPECIFICATION}

The data used in our analysis are from the Wage and Earnings Survey (WES) of the National Labor Center in Hungary, and contain information on wages, education, type of employment, and other demographic information. We use data from the seven years of 1986, 1989, 1992, 1995, 1998, 2001 and 2004 to cover the communist and transition periods. Wage earners are selected following a systematic, random selection procedure. Details of the sampling procedure are documented in Supplemental Appendix S.3. Considerable effort went into assuring that variables are coded consistently over time. This was carried out with assistance from the National Labor Center and the Hungarian Central Statistical Office and involved substantial recoding of the data. ${ }^{6}$

Wage equations are estimated using a standard Mincer equation, taking the form:

\footnotetext{
${ }^{6}$ Campos and Žlábková (2001) give details on how consistent definitions of industry, ownership, and occupation codes were obtained.
} 


$$
\ln \left(\mathrm{w}_{\mathrm{i}}\right)=\beta_{1} \mathrm{~S}_{\mathrm{i}}+\beta_{2} \mathrm{E}_{\mathrm{i}}+\beta_{3} \mathrm{E}_{\mathrm{i}}^{2}+\boldsymbol{\beta}_{4} \mathbf{X}_{\mathrm{i}}+\varepsilon_{\mathrm{i}}
$$

where the i subscript denotes the individual, w is wages, $\mathrm{S}$ is years of schooling (or, in some specifications, types of education), $\mathrm{E}$ is potential experience, and $\mathbf{X}$ contains a set of variables to control for institutional and demographic characteristics as well as spatial price differences. Each of these variables is described in more detail below.

The monthly value of wages used in our analysis is the sum of the official base wage received and other payments to the employee (rewards given in the reference month, provisions, overtime work, shift work, other special payments, e.g. in mining). In addition, the value of wages includes a pro-rated estimate of irregular payments (1/12 of irregular payments in the previous year).

Two measures of schooling are examined in this paper. The first measure is a vector of six dummy variables that denote the highest type of completed schooling. The school types include primary, three types of secondary (vocational, technical, and gymnasium or general), college, and university. ${ }^{7}$ In 2004,17 percent of wage earners had only primary schooling or less, while 21 percent had college or university education. Of the remaining 62 percent who completed some form of secondary schooling, slightly less than half of these wage earners attended vocational school (29 percent of the total). The second measure of schooling is an estimate of years of school attainment, which is created by converting the data on highest school type completed into years of schooling. The average value of this variable increased from 9.7 in 1986 to 11.5 in 2004. Potential experience is constructed as the wage earner's age less six years and less years of schooling.

The variables designated by $\mathbf{X}$ include a set of eight dummy variables to control for

\footnotetext{
${ }^{7}$ The omitted category is those individuals with less than primary schooling.
} 
differences across industries, ${ }^{8}$ a dummy variable for large firms (those with more than 300 employees), and a gender dummy to control for the large difference in wages across the sexes. The set of control variables also contains a dummy for each of the 19 counties of Hungary and for the capital, Budapest. These spatial-specific variables control for any variation that is specific to Budapest or some particular county. In particular, these dummy variables control for spatial variation in prices, which is likely to be significant with wages and prices in Budapest higher than other regions. The county dummy variables will also control for region-specific differences in labor markets, which are also potentially important given that unemployment rates are relatively lower in Budapest, the counties along the Budapest-Vienna highway, and the counties along the Hungarian-Austrian border. Similarly, the county dummies will control for the potential measurement issue that a year of schooling may result in different levels of human capital accumulation over different regions if there are differences in schooling quality across regions. ${ }^{9}$

The controls for firm size and industry, as well as the county fixed-effects, reduce the potential for omitted variable bias in our estimation of equation (1). Having data that has been collected using the same survey instrument over the years of 1986 to 2004 also significantly improves the credibility of measured changes. Frequently, comparisons over time come from different data sources and one is left with the question of whether the change over time is a

\footnotetext{
${ }^{8}$ The eight classifications are: industry, construction, transportation and telecommunications, trade, water, services, health and social services, and public services. The excluded classification is agriculture.

9 The number of observations varies across the years of the survey and is lowest for 1992. The decline in the 1992 sample size is due to two reasons. First, there was a planned reduction in sample size for 1992, which was driven by changes in the sample design. Second, the non-response rate increased immediately after the collapse of communism. Because the survey takes place in first semester, 1992 is our first data point after the fall of communism (as the 1989 survey was still carried out before the collapse of the regime). The sample size increases again in 1995, as smaller firms were added to the frame. For example, in 1986 one out of every seventh manual employee was selected into the sample. Starting in 1992, all manual employees born on the $5^{\text {th }}$ and $15^{\text {th }}$ of each month (or approximately two out of every thirty manual employees) were selected.
} 
consequence of actual changes in the population, or is simply the result of changing the survey instrument. These are important advantages to using the WES data.

The primary disadvantage of using the WES data is that the choice of variables is small and our ability therefore to empirically address violations of the OLS assumptions is limited. ${ }^{10}$ In particular if education is correlated with the residual, which can occur for several reasons, including if people select into (or out of) the sample based on some characteristic that is correlated with education, then the OLS estimator is biased. For example, if persons with high returns are more likely to be wage earners and those with expected low returns opt out of the sample, then this induces correlation and results in sample-selection bias. ${ }^{11}$ This source of bias is typically corrected by modeling the selection decision, but this requires data on the individuals who have opted out of the wage market. Because we have information only on wage earners, we can not pursue this approach. However, we argue that the unique features of the labor market in 1986 provide us with important information that we can exploit to try to reduce sample-selection bias.

A fundamental characteristic of the centrally-planned economies was that workers had limited ability to select in or out of the wage market. In principle, all persons of working age were required to work, official unemployment was close to zero, and the opportunity to choose to work in non-wage employment was highly limited. An implication of this lack of freedom to select out of the wage market is that the pre-transition, 1986 WES estimates of the wage equation (1), will be less susceptible to sample-selection bias. ${ }^{12}$

\footnotetext{
${ }^{10}$ As noted above, we regard the lack of information on actual hours worked and data on selfemployment, albeit common in this literature, as an important drawback of our data.

${ }^{11}$ For East Germany from 1990 to 1994, Hunt (2002) finds that the 10 point improvement in the gender wage gap is a result of the reduction of participation of low wage women in the labor market.

${ }^{12}$ Munich, Svejnar and Terrell (2002) note that "In addition to regulating wages, the central planners regulated employment and admissions to higher education. With minor exceptions, all able-bodied adults
} 
Access to the 1986, pre-transition data is a unique feature of this analysis that allows us to mitigate selection bias in the later, post-1986 years. Our principal assumptions are that sample selection bias was minimal in 1986 and that the decision to participate in the wage market after 1986 is correlated with age, gender and schooling demographics. ${ }^{13}$ We assume that the change in these demographic variables in the post-1986 WES data comes from people selecting in and out of the wage market. We then re-weight the data to have the same demographic composition as in 1986 and thereby purge labor supply changes from the data. We argue that this re-weighting results in a counter-factual conditional wage distribution which corrects for (that is, reduces) overt sample selection bias.

This methodology is similar to that developed by DiNardo, Fortin and Lemieux (1996), who propose a semi-parametric estimation strategy to answer questions such as: what would the distribution of wages now be, if worker's attributes had remained as before. They note that the methodological contribution of their paper is to show that the estimation of such counterfactual densities can be "greatly simplified by the judicious choice of a reweighting function" (1996, p. 1009). ${ }^{14}$ In this paper, we generate a baseline density by treating our 1986 sample as one in which sample-selection bias is the least severe, and re-weight the other six years according to the demographic distribution of the 1986 sample. More specifically, we partition each of the WES samples into six age categories (under 30, 30-34, 35-39, 40-44, 45-49, 50 and over), the seven

were obliged to work. Jobs were provided for everyone and employment security was assured" (2002, p. 6). Horvath et al. (1999) show that the registered unemployment rate in Hungary increased rapidly with the launching of reforms in the late 1980s yet reaching 1.4\% in 1990. In terms of labor market participation, data provided in Fazekas and Koltay (2006, p. 234) show rapid declining rates, from 79.4 in 1980. to 75.9 in 1990, to 61.4 in 2000 (the respective values for males were 85.4, 81.0 and 65.5, while for females they were 72.8, 70.3 and 56.9). See Supplemental Appendix S.1 for further details.

${ }^{13}$ Svejnar (1999) and Boeri and Terrell (2002) observe that early retirement schemes, youth unemployment and the reduction of female labor force participation rates are stylized facts of the post1989 transition.

${ }^{14}$ It is useful to note that DiNardo argues that "It is therefore clear that this propensity score reweighting is merely a special case of the Heckman selection framework." (2002, p. 16). 
school types described above and sex; for a total of 84 age-sex-education categories. We then define the proportion of the population that belongs to each of these categories in year $\mathrm{t}$ as:

$$
v_{\mathrm{k}}^{\mathrm{t}} \equiv \sum_{\mathrm{i}}^{\mathrm{j}_{\mathrm{k}}} \omega_{\mathrm{i}, \mathrm{k}}^{\mathrm{t}} / \sum_{\mathrm{i}}^{\mathrm{j}_{\mathrm{k}}} \sum_{\mathrm{k}}^{\mathrm{K}} \omega_{\mathrm{i}, \mathrm{k}}^{\mathrm{t}}
$$

where the $\mathrm{k}$ subscripts runs from 1 to $\mathrm{K}$ and represents the 84 age-sex-education categories, $\mathrm{i}$ subscripts the individual observation and runs from 1 to $\mathrm{j}_{\mathrm{k}}$ for each of the $\mathrm{k}$ categories, and $\omega_{\mathrm{i}, \mathrm{k}}$ represents the weight or expansion factor for individual i in category $\mathrm{k}$.

To re-weight the data such that the demographic composition in later years matches the composition from 1986, we construct new weights for each year:

$$
\bar{\omega}_{\mathrm{i}, \mathrm{k}}^{\mathrm{t}}=\left(v_{\mathrm{k}}^{86} / \mathrm{v}_{\mathrm{k}}^{\mathrm{t}}\right) \omega_{\mathrm{i}, \mathrm{k}}^{\mathrm{t}} \quad \forall \mathrm{k} \in \mathrm{K}
$$

The $v^{86}$ term in the numerator adjusts the weights to reflect the demographic composition in 1986, and the $v^{t}$ in the denominator normalizes the adjustment to ensure that the sum of unadjusted weights equals the sum of adjusted weights.

What is the intuition? Consider for example that low-educated, young males comprise a larger proportion of the sample in 1986 than in 1995. What this method does is to adjust upwards their 1995 weights (in this example) to ensure that they represent the same proportions across both years. One difficulty with this approach is that it doesn't allow for any true population changes in the age, sex and education composition of the sample. ${ }^{15}$ While this affects the interpretation of the results, it is in some ways a desirable characteristic. Changes in returns to education can result from changes in the composition of the labor force and from how the labor

\footnotetext{
${ }^{15}$ The Hungarian Central Statistical Office reports that the Hungarian population declined by about 2 percent between 1990 and 1998 and has also aged slightly during this period.
} 
market rewards education, conditional on the labor market characteristics. By re-weighting the data to the 1986 demographic composition, we purge from our analysis changes in labor supply and focus on market changes in the demand for wage labor. This focus allows us to examine whether firms are responding to reforms by providing greater returns to investment in human capital.

\section{RESULTS}

In order to examine how returns to schooling have changed from 1986 to 2004, county fixedeffects estimates of equation (1) are provided in Tables 1 to 4 . Panel B of Table 1 provides fixedeffects estimates for all firms with more than 50 employees. Panel A and all the other tables report fixed-effects estimates for the same sample except that all are weighted following the formula above and therefore represent our estimates that have been corrected for selection on observables. The standard errors listed in all tables are corrected for heteroscedasticity of unknown form through use of the 'sandwich variance estimator'. ${ }^{16}$ The disadvantage, as noted by Kauermann and Carroll (2001), is that the sandwich variance estimator is inefficient and often results in estimated standard errors that are too conservative (large). Given the large sample sizes, the cost of the 'sandwich' or robust variance estimates are not qualitatively important, and the benefit of consistency is desirable.

The results from Panel B of Table 1 show that the uncorrected returns to a year of schooling increased by 123 percent from a return of 6.1 percent in 1986 to 13.6 percent in 2004. ${ }^{17}$ Once we account for sample selection on observables, the increase in returns is smaller suggesting that the positive correlation between education and the decision to participate in the

\footnotetext{
${ }^{16}$ An advantage of the WES design is that the sample was selected in a single stage, and there is therefore no need to correct estimates of the sampling variance for any sort of design-induced dependence.

${ }^{17}$ This increase in returns is statistically significant.
} 
wage sector we discussed above is indeed present. Panel A shows that the selection-corrected return to schooling for wage earners from firms with 50 or more employees increased by only (vis-à-vis the uncorrected estimates) 75 percent from 6.1 percent in 1986 to 10.7 percent in 2004. This result supports the hypothesis that central planners undervalued education and the market has quickly corrected this. ${ }^{18}$

A comparison of the panels shows that the sample-selection bias is positive and quite large throughout the period of analysis. The direction of the bias is consistent with the notion that persons who expect to receive higher returns in the wage market, choose to enter while those who expect lower returns, opt out. Interestingly, the decision of workers to select in and out of the sample appears to happen rather quickly. By 1992 the magnitude of the bias is over 10 percent and stays always above this level throughout the 1990s. ${ }^{19}$

Table 1 also provides evidence on decreasing returns to experience throughout the transition from centrally planned to market economy. This result appears to support the notion that labor market experience acquired under communism looses value after the introduction of economic reform. ${ }^{20}$ It is also worth stressing that there is still little research focusing on the returns to experience in the labor market (Fleisher et al., 2005) and, consequently, future research would do well in investigating this issue in depth.

Under communism, a substantial share of the labor force was employed in large state-

\footnotetext{
${ }^{18}$ The declining magnitude on the male coefficient indicates that the premium to male earners is falling over time, indicating relative improvement for women in the labor force. In Jolliffe and Campos (2005), we examine in detail, via traditional Oaxaca decompositions, the changing gender wage gap over time. ${ }^{19}$ Note that in this paper we restrict our analysis to only those firms with 50 or more employees. While this restriction corrects for the change made to the sample frame in 1995, it comes with the disadvantages that our analysis excludes wage earners working in smaller firms. Examination of the full sample reveals that the restriction on the sample does not affect the qualitative nature of the results.

${ }^{20} \mathrm{We}$ are grateful to an anonymous referee for pointing out the need for care in the interpretation of returns to experience using cross sectional data, like ours. If returns to experience are rising, but at a diminishing rate, cross sectional returns might underestimate the life-cycle returns for newer cohorts (see, for example, Noorkôiv et al., 1998).
} 
owned industrial enterprises. Thanks to government subsidies, those firms were able to survive with minimal technological modernization. Consequently, at the outset of transition a considerable share of workers had skills that were relevant for production technologies that were by and large obsolete in the rest of the world (or certainly in the OECD countries). One thus expects that returns to the skill of those in manufacturing would be lower than returns to skill of workers in other sectors (especially services). Table 2 shows our estimates of the returns to skill from 1986 to 2004 in eight sectors, again based on the sample of wage earners in firms with 50 or more employees.

One noteworthy result from Table 2 is the difference between the changes in returns to education from 1986 to 2004 in say services, on the one hand, and agriculture and construction, on the other. Indeed, the largest increases in returns to schooling are found in the service industries, with returns increasing by 91 percent. Correspondingly, the share of college educated workers in the service industry doubled from 6 to 12 percent between 1986 and 2004, suggesting an increase in demand for greater skill. In construction, returns actually declined over this time period and in agriculture they increased, but only by 27 percent. Similarly, the share of college educated workers in these two industries declined from 42 to 6 percent over the period of analysis. These results are consistent with the notion that the planned economy under-valued skilled labor used in the production of non-physical goods and services.

There are several potential explanations for the varying returns to types of schooling during transition. One explanation is that different types of schooling produce different skill sets and these skills may be more or less well suited to the needs of the new market economy. Another related explanation is that the government traditionally steered students into certain types of schools and this planned aspect of the economy no longer provided the correct mix of 
skills. Both of these explanations are based on the idea that the changing market environment produced changes in the market value of certain skills. These hypotheses ignore the fact that under the planned economy, returns to skills were set by planners and not determined by the market. Prior to transition, wage setting was used to favor certain industries and certain types of labor. To this end, labor that had been trained in technical and vocational schools and was involved in the production of certain goods tended to be more highly valued, while labor that had been more academically trained and less likely working in the physical production of goods was less highly valued. Presumably, the market economy rewards the value added by labor and is indifferent as to whether the added value is in terms of some physical commodity or, for example, in terms of some service.

Table 3 lists the wage premium to each of the six types of schooling (ranging from primary to university) over time. One interesting result is that the wage premium to primary and vocational schooling actually declines between 1986 and 2004. This result is striking given the large increase in the return to a year of schooling we observe over this very same time period. Another result shown in Table 3 is that the largest percentage change in the wage premium is for those wage earners who completed university, college or secondary general education. These results are consistent with the view that the planned economy under-valued (relative to the market economy) labor used in the production of non-physical goods and services.

One indication that students are responding to the changing structure of returns by school type is that the share of students in general education increased from 24 percent in 1990 to 28 percent by 1997 (Fretwell and Wheeler, 2001). This finding also provides empirical evidence supporting the theoretical argument of Nelson and Phelps (1966) and Schultz (1975) that general education may enhance an individual's ability to adapt to a changing market environment. In 
contrast, the value of training in specific technical skills is more dependent on market fluctuations. When skills training is well targeted to the specific demands of the market, then returns are high; when market and technology conditions change, there will be a time lag before curricula can adjust to provide the newly demanded mix of skills. This result further adds to the discussion of the relative benefits of general education versus training in specific skills.

Finally, Table 4 explores whether there is any evidence of qualitative changes in schooling post-1989 (the fourth effect mentioned in the introduction). One hypothesis is that schools post-1989 have responded to the changing market needs, and provided more marketable skills. A competing theory is that because the era of transition has seen large declines in education budgets for many countries, including Hungary, the quality of education has declined. Immediately post-1989, total public expenditures on education as a percent of gross domestic product increased in Hungary from 5.7 percent in 1989 to 6.6 percent in 1992. During the next five years though, expenditure declined by 35 percent reaching a low of 4.4 percent in 1997 (Berryman, 2000). ${ }^{21}$ As a result of the declining expenditures on education post-1992, studies note that many teachers have had to take on second jobs (Fretwell and Wheeler, 2001) and that academic performance has been declining (World Bank, 1997). While we have no direct measures of school quality in the WES data, we do provide some limited evidence supporting this latter view. ${ }^{22}$ Up to 1992 , all wage earners acquired their schooling prior to transition or while education expenditures were increasing. By 2004, the youngest wage earners in our sample acquired essentially all of their schooling during the post-1989 years, and most all of it during

\footnotetext{
${ }^{21}$ As one example, the "Bokros package" of 1995 reduced allocations for salaries of staff at higher education facilities by 20 percent (World Bank, 1998). The Bokros package refers to a series of fiscal austerity measures imposed by then-Finance Minister Bokros in response to a severe fiscal crisis.

${ }^{22}$ There is an extensive literature on school quality in non-transition countries. See, among others, Behrman and Birdsall (1983), Betts (1995), Card and Krueger (1992), and Glewwe (1999).
} 
the post-1992 period of declining expenditures. By contrasting the returns for the youngest wage earners in the WES sample with all others, we can observe whether the market considers schooling attained in the transition years more or less highly.

In 1986, the returns to schooling for those 20 years of age and younger were about 61 percent less than the returns for persons over 20 years of age. In the early years of transition, this gap narrowed and by 1992 the difference stood at 17 percent. The difference in returns, though, increased over the next six years and by 1998, wage earners who were schooled in the post-1989 years had returns that were 163 percent less than the returns for those who received most of their schooling prior to 1989. During the first few years of transition, the youngest wage earners were experiencing the largest increases in the returns to schooling while after 1992, the returns to education stagnated for the youngest workers while returns continued to increase for older workers. ${ }^{23}$ This is consistent with the hypothesis of declining school quality and, if this is correct, could have negative repercussions on future economic growth and on the earnings potential of the generation that attained its education during the post-transition years. ${ }^{24}$

We recognize, however, that there are additional plausible explanations for this finding. One of them, for instance, would be that if over time young people are increasingly likely to pursue schooling beyond the secondary level, and if these are the most able, there would likely be more able youth sorted out of the under-20 cohort earnings equation. Another possibility is that the higher estimated returns for the older group may be due to the increasing share of more educated (college and university) workers in this group. A third potential explanation is that our results reflect changes in returns to experience which are difficult to sort out from changes in the

\footnotetext{
${ }^{23}$ As the number of graduates from institutions of higher education in Hungary increased over the transition period, an alternative explanation for the decline in returns to education for the young is a simple supply-side story.

${ }^{24}$ See Fan, Overland and Spagat (1999) for a theoretical discussion of this possibility.
} 
quality of education. Finally, this finding can also be explained by the fact that young workers may be the most adversely affected by market regulations that constrain job creation, and the slow down and slight reversal of liberalization in the late 1990s could be taken as support for this hypothesis. Unfortunately, our data does not allow us to discriminate among these. However, we stress that none of these hypotheses would appear to suggest that young workers are natural winners from market reforms.

\section{CONCLUSIONS}

In this paper, we studied the effects of the introduction of economic reform -the transition from centrally planned to market economy - on the labor market. We tried to improve upon the existing reform literature by focusing on a highly effective reform, defined broadly and covering the periods before, during and after its implementation. One important result in this paper is that returns to schooling are relatively large throughout the Hungarian transition (which is a standard example of gradual reform), at around 10 percent and above since 1995 . The returns to a year of schooling increased by 75 percent from 6.1 percent in 1986 to 10.7 percent in 2004, using our preferred (selection-corrected) estimates. While these returns are larger than those available for other transition economies and for Western Europe, we believe they are credible estimates for several reasons.

While many East European countries have education levels that are on par with Western Europe, average wages continue to be lower. Since estimated returns to schooling are measured in terms of a percentage change in wages, if West and East European markets were to provide similar returns to schooling in terms of wage levels, then this means higher returns from estimating Mincer equations such as equation (1). Our prior assumption is that if markets are 
truly liberalized, then rates of returns in transition countries will be higher than those found in West Europe until there is some convergence in wage levels.

We believe that the difference found in our estimates may be in part based on some unique characteristics of the data we examine. Our data was collected using the same survey instrument over the years of 1986 to 2004 , covering pre- as well as transition years. Studies that are based on multiple survey instruments for the temporal analysis face the difficult question of whether the observed change results from changes in the examined population or changes in the survey instrument. Further, our data was re-coded to current standard international classifications to minimize errors in comparisons over time.

The unique characteristics of the WES data allow us to explore the important issue of school quality. Because the WES sample sizes are large, we are able to estimate wage equations for a small sub-sample of very young workers in each of the seven years. Our analysis reveals that the returns to education for the generation that received much of its schooling post-1989 declined during the mid and late 1990s, while returns for older workers continued to increase during this period.

Use of the WES data though, imposes difficult estimation issues similar to those faced with using any labor force survey for estimating returns to schooling. In particular (and as with essentially all labor force surveys), the researcher has no information on the population that chose not to participate in the wage market and therefore can not control for sample-selection bias. Our approach to correct for this potential bias has been to exploit the somewhat unique fact that we have representative data from 1986, well before the transition began and when workers had very limited choice as to whether they would participate in the wage sector. Our estimation strategy in essence is to use the demographic composition (based on 84 age-sex-schooling 
classifications) of the 1986 data as a basis to identify which types of people disproportionately select in or out of the sample in later years.

We argue that the 75 percent increase in returns to a year of schooling between 1986 and 2004 is evidence that the planned economy under-valued education and liberalization has allowed the markets to correct this. By examining returns by type of schooling rather than an aggregated measure of years of schooling, we shed further light on whether the type of schooling received in pre-transition Hungary proved to be appropriate for the liberalized, post-1989 market. The common assumption is that socialist economies under-valued and under-supplied general education. Our analysis strongly supports this view. We note that after 1989, an increasing proportion of students have been choosing to attend general school over vocational and technical schooling. In spite of this increasing supply of students in general schooling, the estimated wage premiums to university and college education increased by more than 60 percent between 1986 and 2004. This is in contrast to the premiums to secondary vocational training, which decreased by 33 percent over this time period.

The empirical evidence in this paper supports the belief that the liberalized economy has responded to market forces and is providing large returns for human capital investments. The evidence also suggests that wage earners are responding to the changes in the market and making better investment choices. All of this bodes well for future growth. The potential caveat to this conclusion, though, is that the declines in public expenditures on education may have resulted in a decline in the quality of this investment and the markets seem also to have responded to this. 


\section{REFERENCES}

Berryman, Sue. 2000. Hidden Challenges to Education Systems in Transition Economies, Washington, D.C.: The World Bank.

Behrman, Jere and Birdsall, Nancy. 1983. “The Quality of Schooling: Quantity Alone is Misleading." American Economic Review, 73(5): 928-946.

Betts, Julian. 1995. "Does School Quality Matter? Evidence from the National Longitudinal Survey of Youth.” Review of Economics and Statistics, 77(2): 231-250.

Boeri, Tito and Katherine Terrell. 2002. "Institutional Determinants of Labor Reallocation in Transition," Journal of Economic Perspectives, 16 (1): 51-76.

Card, David. 1999. "The Causal Effect of Education on Earnings," in O. Ashenfelter and D. Card (eds) Handbook of Labor Economics Volume 3. Amsterdam: Elsevier.

Card, David and Krueger, Alan. 1992. "Does School Quality Matter? Returns to Education and the Characteristics of Public Schools in the United States." Journal of Political Economy, 100(1): 1-40.

Campos, Nauro and Žlábková, Dana. 2001. “The Wrong Mix: A First Look at Occupational Mobility during the Hungarian Transition,” Prague: CERGE-EI DP 59.

Campos, Nauro and Horvath, Roman. 2006. "Reform Redux: Measurement, Determinants and Reversals,” Bonn: IZA Discussion Paper No. 2093.

DiNardo, John, Fortin, Nicole and Lemieux, Thomas. 1996. "Labor Market Institutions and the Distribution of Wages, 1973-1992: A Semiparametric Approach.” Econometrica, 64(5): 1001-1044.

DiNardo, John. 2002. "Propensity Score Reweighting and Changes in Wage Distributions", University of Michigan, mimeo. 
Fan, Simon, Overland, Jody and Michael Spagat. 1999."Human Capital, Growth and Inequality in Russia." Journal of Comparative Economics, 27 (4): 618-643.

Fazekas, Karoly and Jeno Koltay (eds.). 2006. The Hungarian Labour Market: Review and Analysis, Budapest, Institute of Economics.

Fleisher, Belton M., Sabirianova, Klara, and Wang, Xiaojun. 2005. "Returns to Skills and The Speed of Reforms: Evidence from Central and Eastern Europe, China, and Russia," Journal of Comparative Economics, 33: 351-370.

Fretwell, David and Wheeler, Anthony. 2001."Hungary: Secondary Education and Training," Washington, D.C.: The World Bank.

Glewwe, Paul. 1999. The Economics of School Quality Investments in Developing Countries: An Empirical Study of Ghana. New York: St. Martin's Press.

Harrison, Ann and Gordon Hanson. 1999. "Who Gains from Trade Reform? Some Remaining Puzzles," Journal of Development Economics, 59 (1): 125-154.

Horvath, Reka, Abraham, Arpad, Horvath, Tibor and Tams Kopeczi-Bocz. 1999. "Background Study on Employment and Labour Market in Hungary,” Barcelona: European Training Foundation.

Hunt, Jennifer. 2002. "The Transition in East Germany: When is a Ten Point Fall in the Gender Wage Gap Bad News?” Journal of Labor Economics, 20 (1): 148-169.

Jolliffe, Dean and Nauro Campos. 2005. "Does Market Liberalisation Reduce Gender Discrimination? Econometric Evidence from Hungary, 1986-1998," Labour Economics 12: $1-22$.

Kauermann, Göran and Carroll, Raymond. 2001. "A Note on the Efficiency of Sandwich Covariance Matrix Estimation." Journal of the American Statistical Association, 
96(456):1387-1496.

Munich, Daniel, Svejnar, Jan and Katherine Terrell. 2002. "Returns to Human Capital under the Communist Wage Grid and During the Transition to a Market Economy," Ann Arbor: William Davidson Working Paper Number 272a.

Nelson, Richard and Phelps, Edmund. 1966. "Investment in Humans, Technological Diffusion, and Economic Growth." American Economic Review, 56(2): 69-75.

Noorkôiv, Rivo, Orazem, Peter, Puur, Allan, and Vodopivec, Milan. 1998. "Wage dynamics in Estonia, 1989-1995", Economics of Transition, Vol. 6 pp.481-503.

Rodrik, Dani. 1996. “Understanding Economic Policy Reform,” Journal of Economic Literature 34 (1): 19-41.

Schultz, Theodore. 1975. "The Value of the Ability to Deal with Disequilibria." Journal of Economic Literature 13(3): 827-46.

Svejnar, Jan. 1999. "Labor Markets in the Transitional Central and East European Economies." In Orley Ashenfelter and David Card, Eds., Handbook of Labor Economics, Vol. 3, pp. 2809-2857. Amsterdam, London and New York: Elsevier, North-Holland.

World Bank. 1997. "The Effect of Education Decentralization Reforms on Resource Allocation, Quality, and Equity in Hungarian Schools," in Abstracts of Current Studies: Labor Markets and Education, Washington, D.C.: The World Bank.

World Bank. 1998. Republic of Hungary Higher Education Reform Project: A Staff Appraisal Report, Report No. 16536-HU, Washington, D.C.: The World Bank. 
Figure 1.

Liberalization Index: Hungary and Transition Economies Average, 1989-2001

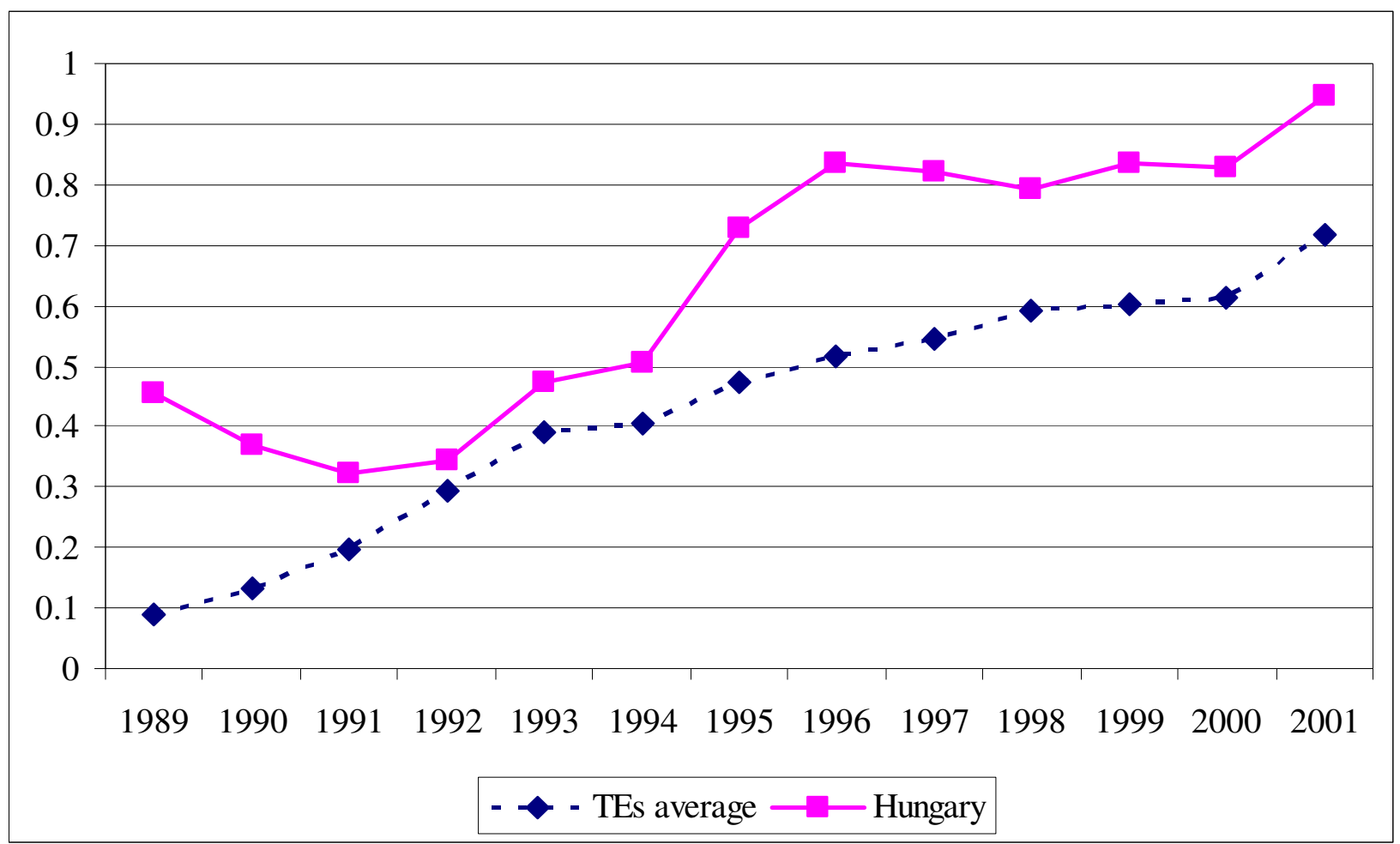

Source: Campos and Horvath (2006) 
Table 1. Returns to Years of Schooling, 1986-2004

Spatial and Industry Fixed-effects Estimation of Equation (1)

\begin{tabular}{lccccccc}
\hline \multicolumn{1}{c}{} & $\mathbf{1 9 8 6}$ & $\mathbf{1 9 8 9}$ & $\mathbf{1 9 9 2}$ & $\mathbf{1 9 9 5}$ & $\mathbf{1 9 9 8}$ & $\mathbf{2 0 0 1}$ & $\mathbf{2 0 0 4}$ \\
\hline Panel A: Selection-corrected & & & & & & & \\
Years of Schooling & 0.061 & 0.073 & 0.082 & 0.098 & 0.104 & 0.108 & 0.107 \\
& $(0.0004)$ & $(0.0004)$ & $(0.0009)$ & $(0.0009)$ & $(0.0012)$ & $(0.0012)$ & $(0.0010)$ \\
Dummy: Male=1 & 0.280 & 0.295 & 0.216 & 0.169 & 0.163 & 0.171 & 0.178 \\
& $(0.0022)$ & $(0.0024)$ & $(0.0070)$ & $(0.0043)$ & $(0.0055)$ & $(0.0050)$ & $(0.0042)$ \\
Potential Experience & 0.028 & 0.021 & 0.024 & 0.020 & 0.018 & 0.013 & 0.015 \\
& $(0.0003)$ & $(0.0004)$ & $(0.0011)$ & $(0.0008)$ & $(0.0010)$ & $(0.0010)$ & $(0.0008)$ \\
Experience Squared & -0.041 & -0.028 & -0.031 & -0.018 & -0.015 & -0.011 & -0.014 \\
$\quad$ / 100 & $(0.0007)$ & $(0.0008)$ & $(0.0024)$ & $(0.0018)$ & $(0.0024)$ & $(0.0024)$ & $(0.0018)$ \\
Firm Size: & -0.009 & -0.002 & -0.024 & -0.139 & -0.171 & 0.123 & 0.142 \\
300+ Employees & $(0.0051)$ & $(0.0022)$ & $(0.0093)$ & $(0.0042)$ & $(0.0051)$ & $(0.0056)$ & $(0.0047)$ \\
& & & & & & & \\
Observations: & 149,274 & 383,720 & 48,261 & 371,882 & 334,207 & 346,217 & 431,391 \\
R-squared: & .45 & .40 & .39 & .38 & .38 & .40 & .40 \\
Panel B: Uncorrected Estimates & & & & & & \\
Years of Schooling & 0.061 & 0.078 & 0.096 & 0.112 & 0.117 & 0.126 & 0.136 \\
& $(0.0004)$ & $(0.0004)$ & $(0.0007)$ & $(0.0007)$ & $(0.0007)$ & $(0.0006)$ & $(0.0005)$ \\
Dummy: Male=1 & 0.280 & 0.279 & 0.154 & 0.141 & 0.136 & 0.180 & 0.173 \\
& $(0.0022)$ & $(0.0022)$ & $(0.0042)$ & $(0.0036)$ & $(0.0038)$ & $(0.0029)$ & $(0.0027)$ \\
Potential Experience & 0.028 & 0.026 & 0.029 & 0.025 & 0.025 & 0.022 & 0.024 \\
& $(0.0003)$ & $(0.0003)$ & $(0.0007)$ & $(0.0006)$ & $(0.0007)$ & $(0.0005)$ & $(0.0005)$ \\
Experience Squared & -0.041 & -0.037 & -0.036 & -0.028 & -0.030 & -0.031 & -0.034 \\
$\quad$ / 100 & $(0.0007)$ & $(0.0007)$ & $(0.0015)$ & $(0.0013)$ & $(0.0015)$ & $(0.0011)$ & $(0.0009)$ \\
Firm Size: & -0.009 & 0.001 & -0.014 & -0.138 & -0.162 & 0.147 & 0.123 \\
300+ Employees & $(0.0051)$ & $(0.0019)$ & $(0.0054)$ & $(0.0034)$ & $(0.0034)$ & $(0.0031)$ & $(0.0029)$ \\
& & & & & & & \\
Observations: & 149,274 & 383,720 & 48,261 & 371,882 & 334,207 & 346,217 & 431,391 \\
R-squared: & .45 & .41 & .43 & .43 & .44 & .45 & .49 \\
& & & & & & &
\end{tabular}

\footnotetext{
${ }^{a}$ The only statistically insignificant point estimates-1989, Firm Size: 300+ Employees.

Notes: Dependent variable is the log of monthly wages. Sample consists of all firms with 50 or more employees. Standard errors, in parentheses, are robust to heteroscedasticity of unknown form. The eight industry dummy variables are jointly significant and are excluded from the table. County, fixed effects are also jointly significant. All listed point estimates are significant with a $\mathrm{p}$-value of less than $0.01 \mathrm{except}$ for the firm-size dummy. This dummy is significant with a pvalue of less than 0.05 for all except in 1986 and 1989.

Source: Authors' analysis based on the Wage and Earnings Survey data from the National Labor Center of Hungary.
} 
Table 2. Selection-corrected Returns to Years of Schooling by Industry, 1986-2004

Spatial and Industry Fixed-effects Estimation of Equation (1) ${ }^{\mathrm{a}}$

\begin{tabular}{|c|c|c|c|c|c|c|c|c|}
\hline & 1986 & 1989 & 1992 & 1995 & 1998 & 2001 & 2004 & $\begin{array}{l}\text { Change } \\
\text { 1986-04 } \\
\text { (Percent) }\end{array}$ \\
\hline Industry & $\begin{array}{c}0.070 \\
(0.0011)\end{array}$ & $\begin{array}{c}0.070 \\
(0.0015)\end{array}$ & $\begin{array}{c}0.073 \\
(0.0025)\end{array}$ & $\begin{array}{c}0.095 \\
(0.0024)\end{array}$ & $\begin{array}{c}0.097 \\
(0.004)\end{array}$ & $\begin{array}{c}0.114 \\
(0.0026)\end{array}$ & $\begin{array}{c}0.107 \\
(0.0023)\end{array}$ & 53 \\
\hline Construction & $\begin{array}{c}0.058 \\
(0.0013)\end{array}$ & $\begin{array}{c}0.066 \\
(0.0023)\end{array}$ & $\begin{array}{c}0.068 \\
(0.0044)\end{array}$ & $\begin{array}{c}0.082 \\
(0.0045)\end{array}$ & $\begin{array}{c}0.096 \\
(0.0075)\end{array}$ & $\begin{array}{c}0.063 \\
(0.0071)\end{array}$ & $\begin{array}{c}0.032 \\
(0.007)\end{array}$ & -45 \\
\hline Agriculture & $\begin{array}{c}0.052 \\
(0.0007)\end{array}$ & $\begin{array}{c}0.041 \\
(0.0014)\end{array}$ & $\begin{array}{c}0.053 \\
(0.0029)\end{array}$ & $\begin{array}{c}0.067 \\
(0.0029)\end{array}$ & $\begin{array}{c}0.065 \\
(0.004)\end{array}$ & $\begin{array}{c}0.061 \\
(0.0037)\end{array}$ & $\begin{array}{c}0.066 \\
(0.0051)\end{array}$ & 27 \\
\hline $\begin{array}{l}\text { Transport and } \\
\text { Communications }\end{array}$ & $\begin{array}{c}0.080 \\
(0.0045)\end{array}$ & $\begin{array}{c}0.080 \\
(0.0057)\end{array}$ & $\begin{array}{c}0.098 \\
(0.0082)\end{array}$ & $\begin{array}{c}0.115 \\
(0.0068)\end{array}$ & $\begin{array}{c}0.125 \\
(0.0088)\end{array}$ & $\begin{array}{c}0.120 \\
(0.0025)\end{array}$ & $\begin{array}{c}0.112 \\
(0.0036)\end{array}$ & 40 \\
\hline Trade & $\begin{array}{c}0.071 \\
(0.0014)\end{array}$ & $\begin{array}{c}0.078 \\
(0.0025)\end{array}$ & $\begin{array}{c}0.086 \\
(0.0035)\end{array}$ & $\begin{array}{c}0.106 \\
(0.0038)\end{array}$ & $\begin{array}{c}0.136 \\
(0.0042)\end{array}$ & $\begin{array}{c}0.085 \\
(0.0036)\end{array}$ & $\begin{array}{c}0.096 \\
(0.0025)\end{array}$ & 36 \\
\hline Services & $\begin{array}{c}0.064 \\
(0.0015)\end{array}$ & $\begin{array}{c}0.075 \\
(0.002)\end{array}$ & $\begin{array}{c}0.088 \\
(0.0033)\end{array}$ & $\begin{array}{c}0.105 \\
(0.0029)\end{array}$ & $\begin{array}{c}0.126 \\
(0.003)\end{array}$ & $\begin{array}{c}0.112 \\
(0.003)\end{array}$ & $\begin{array}{c}0.122 \\
(0.0028)\end{array}$ & 91 \\
\hline $\begin{array}{l}\text { Health and } \\
\text { Social Services }\end{array}$ & $\begin{array}{c}0.058 \\
(0.0006)\end{array}$ & $\begin{array}{c}0.080 \\
(0.0003)\end{array}$ & $\begin{array}{c}0.073 \\
(0.0025)\end{array}$ & $\begin{array}{c}0.097 \\
(0.0014)\end{array}$ & $\begin{array}{c}0.083 \\
(0.0012)\end{array}$ & $\begin{array}{c}0.074 \\
(0.0009)\end{array}$ & $\begin{array}{c}0.079 \\
(0.001)\end{array}$ & 38 \\
\hline Public Services & $\begin{array}{c}0.078 \\
(0.0006)\end{array}$ & $\begin{array}{c}0.108 \\
(0.0005)\end{array}$ & $\begin{array}{c}0.102 \\
(0.0011)\end{array}$ & $\begin{array}{c}0.115 \\
(0.0007)\end{array}$ & $\begin{array}{c}0.113 \\
(0.0011)\end{array}$ & $\begin{array}{c}0.110 \\
(0.0007)\end{array}$ & $\begin{array}{c}0.110 \\
(0.0007)\end{array}$ & 40 \\
\hline
\end{tabular}

\footnotetext{
${ }^{a}$ Estimated returns are from separate regressions for each industry.

Notes: Dependent variable is the log of monthly wages. Sample consists of all firms with 50 or more employees. Standard errors, in parentheses, are robust to heteroscedasticity of unknown form. The remaining results from estimation of equation (1) are suppressed for the sake of brevity. All point estimates for the experience and gender variables are statistically significant. All listed parameters are statistically significant with a p-value less than 0.001 .

Source: Authors' analysis based on the Wage and Earnings Survey data described in the text.
} 
Table 3. Selection-corrected Wage Premiums by School Type, 1986-2004

Spatial and Industry Fixed-effects Estimation of Equation (1)

\begin{tabular}{|c|c|c|c|c|c|c|c|c|}
\hline & 1986 & 1989 & 1992 & 1995 & 1998 & 2001 & 2004 & $\begin{array}{l}\text { Change } \\
\text { 1986-04 } \\
\text { (Percent) }\end{array}$ \\
\hline \multicolumn{9}{|l|}{ School Types } \\
\hline Primary & $\begin{array}{c}0.085 \\
(0.0049)\end{array}$ & $\begin{array}{c}-0.025 \\
(0.0058)\end{array}$ & $\begin{array}{c}0.068 \\
(0.0114)\end{array}$ & $\begin{array}{c}0.074 \\
(0.0127)\end{array}$ & $\begin{array}{c}0.101 \\
(0.0192)\end{array}$ & $\begin{array}{c}0.166 \\
(.01832)\end{array}$ & $\begin{array}{l}0.048 \\
(.0161)\end{array}$ & -44 \\
\hline $\begin{array}{l}\text { Secondary, } \\
\text { Vocational }\end{array}$ & $\begin{array}{c}0.209 \\
(0.0053)\end{array}$ & $\begin{array}{c}0.087 \\
(0.0063)\end{array}$ & $\begin{array}{c}0.226 \\
(0.0156)\end{array}$ & $\begin{array}{c}0.209 \\
(0.0132)\end{array}$ & $\begin{array}{c}0.222 \\
(0.0203)\end{array}$ & $\begin{array}{c}0.296 \\
(.0189)\end{array}$ & $\begin{array}{c}0.163 \\
(.0169)\end{array}$ & -33 \\
\hline $\begin{array}{l}\text { Secondary, } \\
\text { Technical }\end{array}$ & $\begin{array}{c}0.381 \\
(0.0054)\end{array}$ & $\begin{array}{c}0.388 \\
(0.0063)\end{array}$ & $\begin{array}{c}0.207 \\
(0.0126)\end{array}$ & $\begin{array}{c}0.519 \\
(0.0136)\end{array}$ & $\begin{array}{c}0.546 \\
(0.0201)\end{array}$ & $\begin{array}{c}0.552 \\
(.0184)\end{array}$ & $\begin{array}{c}0.421 \\
(.0162)\end{array}$ & 11 \\
\hline $\begin{array}{l}\text { Secondary, } \\
\text { General }\end{array}$ & $\begin{array}{c}0.303 \\
(0.0059)\end{array}$ & $\begin{array}{c}0.259 \\
(0.0064)\end{array}$ & $\begin{array}{c}0.464 \\
(0.0122)\end{array}$ & $\begin{array}{c}0.475 \\
(0.0141)\end{array}$ & $\begin{array}{c}0.507 \\
(0.0202)\end{array}$ & $\begin{array}{c}0.514 \\
(.0184)\end{array}$ & $\begin{array}{c}0.391 \\
(.0160)\end{array}$ & 29 \\
\hline College & $\begin{array}{c}0.554 \\
(0.0068)\end{array}$ & $\begin{array}{c}0.531 \\
(0.0063)\end{array}$ & $\begin{array}{c}0.765 \\
(0.0128)\end{array}$ & $\begin{array}{c}0.835 \\
(0.0136)\end{array}$ & $\begin{array}{c}0.869 \\
(0.0199)\end{array}$ & $\begin{array}{l}0.989 \\
(.0185)\end{array}$ & $\begin{array}{c}0.939 \\
(.0163)\end{array}$ & 69 \\
\hline University & $\begin{array}{c}0.720 \\
(0.0057)\end{array}$ & $\begin{array}{c}0.741 \\
(0.0067)\end{array}$ & $\begin{array}{c}0.981 \\
(0.0145)\end{array}$ & $\begin{array}{c}1.055 \\
(0.0153)\end{array}$ & $\begin{array}{c}1.166 \\
(0.0218)\end{array}$ & $\begin{array}{l}1.260 \\
(.0191)\end{array}$ & $\begin{array}{c}1.195 \\
(.0166)\end{array}$ & 66 \\
\hline
\end{tabular}

Notes: Dependent variable is the log of monthly wages. Sample consists of all firms with 50 or more employees. Standard errors, in parentheses, are robust to heteroscedasticity of unknown form. The remaining results from estimation of equation (1) are suppressed for the sake of brevity. All point estimates for the experience and gender variables are statistically significant. The firm-size and industry dummies are jointly significant as well as the county, fixed effects. All listed parameters are statistically significant with a p-value less than 0.001 . The point estimate for primary schooling in 1992 has the smallest t-statistic with a value of 10.6. Source: Authors' analysis based on the Wage and Earnings Survey data described in the text. 
Table 4. Comparing Selection-corrected Returns to Education by Age

Spatial and Industry Fixed-effects Estimation of Equation (1)

\begin{tabular}{lccccccc}
\hline & $\mathbf{1 9 8 6}$ & $\mathbf{1 9 8 9}$ & $\mathbf{1 9 9 2}$ & $\mathbf{1 9 9 5}$ & $\mathbf{1 9 9 8}$ & $\mathbf{2 0 0 1}$ & $\mathbf{2 0 0 4}$ \\
\hline 20 Years and & 0.038 & 0.051 & 0.070 & 0.075 & 0.040 & 0.074 & 0.061 \\
$\quad$ Younger & $(0.0040)$ & $(0.0062)$ & $(0.0112)$ & $(0.0114)$ & $(0.0152)$ & $(0.0167)$ & $(0.0165)$ \\
Older than 20 & 0.061 & 0.073 & 0.082 & 0.099 & 0.105 & 0.108 & 0.107 \\
$\quad$ Years & $(0.0004)$ & $(0.0004)$ & $(0.0010)$ & $(0.0009)$ & $(0.0012)$ & $(0.0012)$ & $(0.0010)$ \\
$\mathrm{R}^{2}:$ & & & & & & & \\
20 Years & 0.22 & 0.24 & 0.17 & 0.17 & 0.24 & 0.25 & 0.28 \\
Older than 20 & 0.43 & 0.39 & 0.38 & 0.38 & 0.38 & 0.40 & 0.42 \\
\hline
\end{tabular}

Notes: Dependent variable is the log of monthly wages. Sample consists of all firms with 50 or more employees. Standard errors, in parentheses, are robust to heteroscedasticity of unknown form, and listed point estimates are significant with all p-values less than 0.01 . The remaining results from estimation of equation (1) are suppressed for the sake of brevity.

Source: Authors' analysis based on the Wage and Earnings Survey data described in the text. 